REVIEWS

\title{
Cell cycle and epigenetic changes of plant DNA
}

\author{
G. V. Shevchenko
}

M. H. Kholodny Institute of Botany, NAS of Ukraine

2 Tereshchenkivska Str., 01601, Kyiv, Ukraine

galina-shevchenko@yandex.ru

\begin{abstract}
Plants can apply various strategies to minimize environmental impact. One of the strategies is heritable modifications of gene expression which occur without changing original DNA sequence and are known as epigenetic. Signaling pathway Rb-E2F (retinoblastoma (Rb)-transcription factor E2F/DP) connects the cell cycle with factors, modifying structure of chromatin and DNA. It also coordinates cell proliferation and differentiation influenced by external stimuli. The article highlights the activity of Rb-E2F/DP signaling pathway and its connection with the epigenetic changes of DNA in plants.
\end{abstract}

Keywords: DNA, transcription factor E2F, chromatin-modifying complexes, epigenetic.

Cell division and differentiation, functioning of meristems and general development of plants depend on coordinated activity of the cell cycle genes. Due to constant influence of the environment, the regulation of cell proliferation and differentiation of plants, as well as the relations between the control over cell divisions and the development of vegetative organism became flexible, which allows plants to adjust and survive under various conditions. The regulation of cell cycle consists of multiple points of control over DNA and its epigenetic changes. In case of any damage of DNA structure, a delay in the cell cycle occurs, which is necessary for its reparation, and the mechanisms of protecting DNA from possible damage are established [1].

(C) Institute of Molecular Biology and Genetics NAS of Ukraine, 2010
DNA is most vulnerable at the stage of replication; therefore, one of the main control steps is realized during the transition from $\mathrm{G}_{1}$ - to $\mathrm{S}$-phase. In mammals the $G_{1}-S$ transition usually depends on the activity of E2F/DP transcription factors and repressive retinoblastoma protein $(\mathrm{Rb})[2]$. From the middle of $\mathrm{G}_{1}$-phase the active complex, formed by D-cyclins (the number and activity of which depend on environmental factors [3]) and D-cyclin dependent protein kinases, phosphorylates $\mathrm{Rb}$ (Fig.1). Rb is bound to the E2F/DP transcription factors and represses their activity. Phosphorylated $\mathrm{Rb}$ loses its affinity to the E2F/DP factors, the latter are released and activate the transcription of so called E2F-regulated genes, the promoters of which have E2F binding sites. The E2F-regulated genes provide the progress of cell cycle and DNA synthesis, its replication and restoration, irreversibly directing a cell into the S-phase. 
The importance of the $\mathrm{Rb}-\mathrm{E} 2 \mathrm{~F} / \mathrm{DP}$ signaling pathway was proven by the research, revealing the loss of control over regulation of $\mathrm{Rb}$ and E2F/DP in almost all tumours of mammals [4-6]. It was established that the $\mathrm{Rb}-\mathrm{E} 2 \mathrm{~F} / \mathrm{DP}$-pathway in plants is conservative, the homologues of proteins Rb, E2F, and DP are similar by their structure and biochemical properties to those of animals [7-9], and their expression is limited by the area of meristems (Arabidopsis thaliana) and realized in early S-phase [5].

The screening of plant genomes showed that dicotyledons contain a single gene $R b$, while monocotyledonous have two genes $R b$ [10]. One homologue of animal $\mathrm{Rb}$ was revealed in Arabidopsis [11]; multiple homologues of $\mathrm{Rb}$ - in corn and tobacco [12].

The E2F-transcription factors in resting cells or in the early $\mathrm{G}_{1}$-phase are mainly involved in the repression of a series of genes, which are regulated in the cell cycle, while during the transition from $\mathrm{G}_{1}$ - to S-phase (as a result of release of transcriptionally active E2F-factors) there occurs E2F-dependent activation of several genes, coding for the regulatory proteins and enzymes of nucleotides and DNA synthesis. In plants, the genes, regulated by the E2F transcription factors, are believed to influence postembryonic development and to guide the transition of cells either to division or to differentiation. Such a dual role of E2F- factors explains why transcription factors may be either positive or negative regulators of cell proliferation depending on the type of cells and the stage of their development [13].

It is noteworthy that the $\mathrm{Rb}-\mathrm{E} 2 \mathrm{~F} / \mathrm{DP}$ signaling pathway interacts with the factors, modifying the structure of chromatin (i.e. deacetylase and methyltransferase of histones, SWI-SNF-complex), which are capable of active repressing the transcription of E2F-regulated genes, thus blocking the access of other transcription factors into the area, close to the E2F binding sites [13]. It connects the $\mathrm{Rb}$-E2F/DP-signalling pathway with the epigenetic changes in DNA [14].

In plants, contrary to animals, the changes in activity of any element of the Rb-E2F/DP signaling pathway do not result in lethal effect, which makes plants a convenient model for studying regulation of this pathway.
The investigation on the Rb-E2F/DP pathway and its relations with DNA and chromatin modifying factors may establish the mechanism of coordination between cell proliferation and differentiation depending on environmental factors. The review is aimed at systematization of the data on the Rb-E2F/DP genes activity and their association with the epigenetic regulation in plants.

Family of E2F/DP transcription factors. Initially, E2F was identified as a cell factor, activating E2 adenovirus promoter [15], which gave the factor its name. Later E2F was found to regulate a number of various genes, including the genes of cell cycle and regulatory genes (cyclins, Rb), the genes of DNA] replication and reparation (DNA-polymerases $\alpha$, $C D C 6, O R C 1$ ), and the genes, coding for structural proteins of chromatin (histones) [16].

Arabidopsis genome contains eight genes of proteins, which are structurally related to the E2F family: AtE2Fa (a homologue of animal E2F3), AtE2Fb (E2F1), AtE2Fc (E2F2), two DP proteins (distant-related proteins, AtDPa, AtDPb), and three DEL (DP- and E2F-like, AtDEL1, AtDEL2, AtDEL3 or AtE2F1-3) (ncbi database, http://www.ncbi.org).

The proteins E2F and DP were also found in wheat, tobacco, carrot, and rice [13, 14, and 17]. AtDEL1-AtDEL3 is localized in the nucleus, AtDPa and $\mathrm{AtDPb}$ were revealed in both cytoplasm and nucleus, and AtE2Fa-AtE2Fc may be located in cytoplasm and/or nucleus depending on the type of cells [18].

The E2F transcription factors are also characterized by the presence of a conservative DNA-binding domain, as well as a dimerization domain and a domain of transcription activation, which includes a site of binding to $\mathrm{Rb}$ protein (Fig.1).

In both plants and animals the E2F and DP proteins function as a heterodimeric complex, which provides specificity of binding to DNA. For instance, in Arabidopsis E2Fa (AtE2F3) and AtE2Fb (AtE2F1) are activators of transcription only in cooperation with $\mathrm{DPa}$, while AtE2Fc (AtE2F2) is not transactivated even in the complex with other DP-proteins $[18,19]$. The structure of $\mathrm{E} 2 \mathrm{Fa}-\mathrm{E} 2 \mathrm{Fc}$ is similar to animal proteins including the specific domain of DNA recognition, domain of DP heterodimerization, domain of $\mathrm{Rb}$ binding, and domain of transactivation. And vice versa 

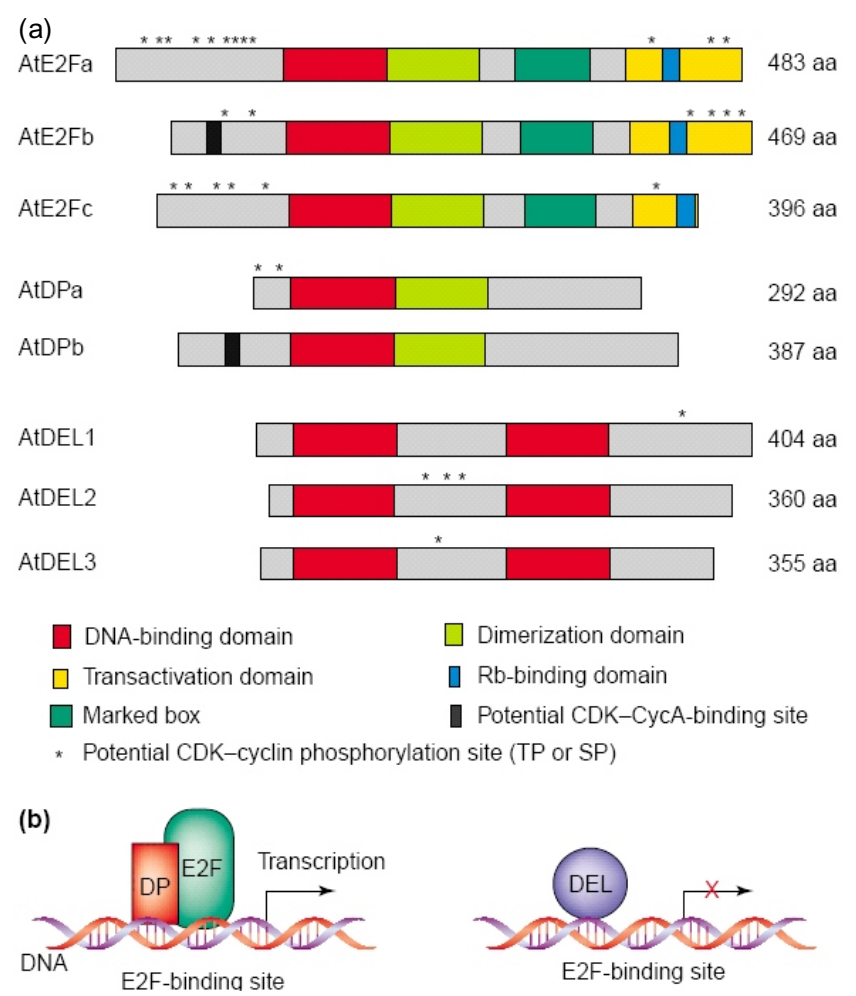

Fig. 1. Domain structur e of proteins E2F/DP [14] (Copyri ght 2002 with permiss ion from Elsevi er)

- E2Fd-E2Ff, the homologues of animal E2F7 and E2F8, do not contain the domain of DP heterodimerization and domain of $\mathrm{Rb}$ binding. Instead, they have a duplicate of the DNA binding domain, which allows them to interact with DNA without dimerization with DP-protein [20, 21]. The] domains of DNA binding in genes E2F and DP include the specific motif of DNA recognition, RRxYD ( $\mathrm{x}$ - any nucleotide).

Since the site of $\mathrm{Rb}$ binding overlaps the domain of E2F activation, the Rb-E2F/DP complex works as a transcription repressor.

Recently, a new class of regulatory proteins DEL (DP- and E2F-like) has been discovered. In Arabidopsis genome they are presented by proteins AtDEL1, AtDEL2, AtDEL3, or AtE2F1-3. This group includes proteins with unique characteristics, which are absent in animal proteins [14]. DEL-proteins contain two E2F-like sites of binding to both E2F and DP, each of them including RRxYD-motif; however, they do not have any domain of activation. Therefore, the monomer protein DEL acts as a competitor to the
E2F/DP-proteins, binding to the same cis-acting elements of the promoter. Since DELs do not have a domain of activation, they function as repressors of the E2F/DP regulated genes [13]. It allows avoiding the $\mathrm{G}_{1}-\mathrm{S}$ transition in conditions, which are unfavorable for the launch of DNA replication (damage of DNA or stress) [11].

The level of transcription of plant genes of E2F family is generally not high. Mainly, they are expressed in organs with actively proliferating tissues (meristems) [5]. The expression of some DP genes increases considerably when a cells enter the S-phase; on the contrary, the members of DEL-family are less expressed in this case [13].

Overexpression of E2F in animals causes the transition to S-phase and development of apoptosis [22]. In Arabidopsis overexpression of $\mathrm{E} 2 \mathrm{Fa} / \mathrm{DPa}$ results in continuous synthesis of DNA without division (endoreduplication), ectopic cell division and pause in the development at early stages [5]. However, in this case apoptosis does not develop. An increase in endoreduplication may be caused by the combination of increased activity of $\mathrm{E} 2 \mathrm{Fa} / \mathrm{DPa}$ and limitation of expression of mitotic genes. The analysis of overexpression of AtE2Fc and DPa in tobacco revealed that the E2F activity is the cause of the launch of S-phase and prolonged cell cycle or its stop; in this case the growth of tissue and organ is modulated either in the presence or in the absence of other factors, associated with the cell cycle (mitotic factors) [9]. However, no clear correlation between the localization of proteins of E2F family and the phases of cell cycle was revealed [14].

Overexpression of E2Fa results in higher amount of cells in plants due to extra-postembryonic cell divisions. For instance, in the roots of Arabidopsis with overexpression of E2Fa and DPa a root cap contains more cells than the control, but they are considerably smaller in size. The surplus of cells in E2Fa-plants may result from either shorter cell cycle or prolonged phase of cell proliferation [5]. E2Fa/DPa is believed to inhibit the extension of cells, as the size of laminas in the transgenic plants with expressed ectopic cell division does not increase, but rather decrease.

[In] Arabidopsis plants, twice-transformed by the genes, coding for both $\mathrm{E} 2 \mathrm{Fa}$ and $\mathrm{DPa}$, the delay in 
growth and twisting of leaves were observed [5] due to increased proliferation of adaxial cells of mesophyll on the exterior side and repression of cell division on the abaxial side [9].

A comparative analysis of nucleotide sequences showed that Arabidopsis has over 30 genes, involved in the regulation of cell cycle, replication and reparation of DNA; these genes contain one or two E2F-binding sites in their promoters $[14,18]$.

The E2F-binding sites were shown to be important for tissue-specific and cycle- regulated expression of some plant genes, responsible for DNA replication [23, 24]. The promoters of genes of ribonucleotide reductase $(R N R)$ and MCM3 in Nicotiana tabacum, Orisa sativa and A. thaliana contain the sites of binding to E2F/DP complexes of plants and regulate S-phase and tissue-specific expression in meristem [18, 23]. Two E2F-binding sites in the promoter $R N R 2$ of tobacco may were revealed to function as activators of gene expression during the $\mathrm{G}_{1}-\mathrm{S}$ transition, while other E2F-binding sites more likely act as repressors of expression in the $G_{1}$ phase. Similarly, one of the E2F-binding sites in MCM3 promoter in Arabidopsis suppresses expression in the $\mathrm{G}_{2}$ - phase. Therefore, the E2F-binding sites are suggested to regulate the $\mathrm{G}_{1}-\mathrm{S}$ transition in both negative and positive way [23].

In general, the increased E2F/DP activity launches cell proliferation and endoreduplication in a cell-specific way, and may cause the morphological changes in certain tissues and organs of transgenic plants. It is noteworthy that the balance between division and differentiation plays a significant role in the development of plants: the delay in differentiation or disorder of cell interaction in various tissues can stop plants growth. Therefore, it is vital to determine, in what way the E2F/DP transcription factors control the $\mathrm{G}_{1}-\mathrm{S}$ transition and how the development of plants takes place.

Association of the Rb-E2F/DP signaling pathway with epigenetic changes in DNA. Cell differentiation is controlled by both activation and silencing of certain genes. A specific type of gene expression should be stable in many generations of cells and remain stable for a long time after the induction signal vanishes. The genetic and biochemical research on yeasts, fruit fly, mammals, and plants demonstrated that changes in gene expression may be accompanied by restructuring of chromatin in gene promoters and other regulatory sites of DNA [25, 26]. In the nucleus, DNA is twisted around octamers, consisting of histones $\mathrm{H} 2 \mathrm{~A}, \mathrm{H} 2 \mathrm{~B}, \mathrm{H} 3$, and $\mathrm{H} 4$. These structures - nucleosomes - are main structural units of chromatin, and regulation of its organization (eu-, heterochromatin) is one of the mechanisms of transcription control. DNA packing into nucleosomes and structures of higher order hinders access of the proteins, binding to DNA- and RNA-polimerases, thus repressing genetic information (heterochromatin). $\mathrm{N}$-terminal of histones of nucleosomes is a subject of such post-translational modifications, as acetylation, methylation, phosphorylation, ubiquitisation, glycosylation, ADF-ribosylation, etc. Along with DNA methylation these modifications promote the transition of nucleosome compaction into either "closed" (transcription repression) or "open" (transcription activation) configuration which mediates transition of signals of cellular response. The transition of specific transcriptional state to daughter cells via mitosis or miosis results in stable inheritance of chromatin structures.

It is known that the Rb-E2F/DP complex is capable of active repressing gene transcription via interaction with various factors of chromatin modifications. Depending on the type of functioning there are two main groups of chromatin-remodeling complexes: 1) ATF-dependent complexes use ATF energy for local destruction or change in association of histones with DNA due to transition of histone octamers to new positions or their temporary elimination from DNA [27-29]; 2) complexes, including histone acetyltransferases (HAT) and histone deacetylases (HDAC), regulate transcriptional activity of genes, determining the level of acetylation of N-terminal domains of nucleosome histones [14].

Activity of SWI-SNF-complex. The most studied chromatin-remodeling factor of the first type is SWI-SNF complex (Fig.2, a). Modern classification of ATF-dependent complexes is based on the type of ATFase, acting as a central catalytic unit. Minimal medullary part of SWI-SNF complex in yeasts, Drosophila, and humans is one ATFase (hBRM or BRG1 in humans and SWI2/SNF or Sth1 in yeasts), 


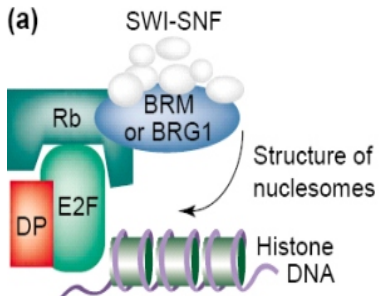

(b)

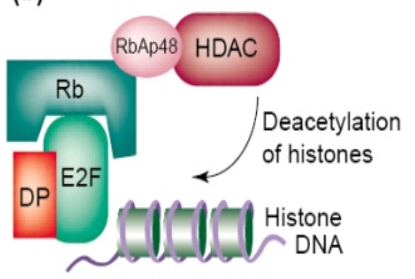

(c)
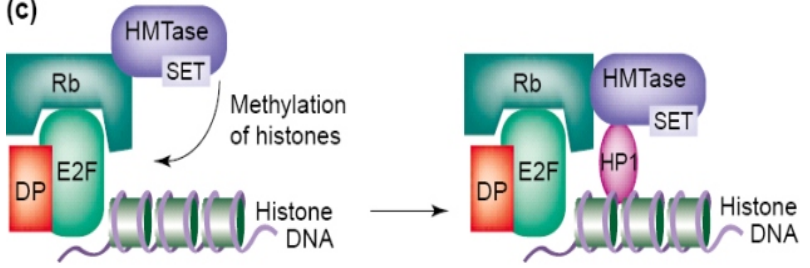

Fig. 2. Association of REb-E2F/DP signaling pathway with: $a$ SWI-SNF-complex; $b$ - deacetylation of histones (HDAC); $c$ methyltransferases of histones [14] (Copyright 2002 with

two zipper-containing proteins SANT/SWIRM/Leu, called SWI3 (BAF155/BAF170 in humans and SWI3/RSC8 in yeasts), and one protein SNF (hSNF5/INI1 in humans and SNF5/SNF1 in yeasts) [30]. SNF2 is the first described ATFase of SWI-SNF complex in yeasts. Besides, ATFase domain, SNF2-like proteins contain various $\mathrm{N}$ - and C-terminal domains for interaction with other proteins of this complex or specific chromatin-associated proteins. SNF2-proteins are divided into several subfamilies depending on the type of these domains: SWI2/SNF2, ISWI and CHD or (LSH)/ DDM1 (lymphoid-specific helicase) [25]. Chromatin- remodeling complexes are not capable of binding DNA directly; they bind to the sites of gene promoters via transcription factors. Most eukaryotes contain multiple SWI-SNF ATFases. For instance, four members of this family were found in Arabidopsis, three - in rice, six - in poplar (nomenclature of Chromo database, http://www.chrombd.org [29, 31]). It was revealed that genomes of Arabidopsis, rice and poplar contain a single gene $\mathrm{BSH}$, similar to SNF5 in yeasts (http://www.chromdb.org), and code for several proteins, similar to SWI2, namely, four homologues of SWI3 - SWI3A, SWI3B, SWI3C, SWI3D (http://www.chromdb.org/ [29]).

In plants, the group of SWI3-proteins is more variable than in animals. In particular, SWI3B is expressed in the whole plant, is localized in the nucleus, and associated with chromatin [32]. The presence of a conservative $\mathrm{Rb}$-binding motif $\mathrm{CxLxE}$ in the mentioned group of proteins presupposes that SWI-SNF-complex participates in regulated $\mathrm{Rb}-\mathrm{E} 2 \mathrm{~F} / \mathrm{DP}$ expression of genes. Several SWI2 homologues in Arabidopsis are highly similar to the analogues of human BRM and BRG1-SWI2 [33]. The interaction of $\mathrm{Rb}$ with $\mathrm{BRM}$ and BRG1 during the early S-phase represses the genes of cyclin-dependent protein kinase $C D K 1$ and cyclin $C y C A$, the products of which are necessary for the $\mathrm{G}_{2}-\mathrm{M}$ transition [34]. It is possible that their plant homologues play the same role.

Protein interactions in the framework of SWI-SNF-complex have not been studied thoroughly. In animals the mutations of the genes of SWI-SNF complex proteins result in the development of tumours which proves its role in the inhibition of oncogenesis [35].

There are data on the interaction of medullary subunits with non-medullary proteins, including cyclins, SNF11 and proteins with so called SET-domain (see below). These proteins, involved into mediation of various functions of SWI-SNF-complex, can be temporarily associated with the latter or present its tissue- or organ-specific additional subunits.

The proteins of SWI-SNF-complex, actin-binding proteins Arp7 and Arp9 [36], facilitate the nucleation of microfilaments. These proteins are assumed to promote the interaction of chromatin-remodeling complexes with other actin-binding proteins or with nuclear proteins, for instance, the components of nuclear matrix or even with chromatin [37]. It is also possible that since actin promotes cell growth, the interaction of Arp7 and Arp9 with chromatinremodeling complexes, regulated via $\mathrm{Rb}$-E2F/DP-signalling pathway, proves the influence of $\mathrm{Rb}-\mathrm{E} 2 \mathrm{~F} / \mathrm{DP}$ on growth processes in cells.

A comparative study on sequences of amino acids and philogenetic analysis of over 40 possible SNF2-like proteins, identified in Arabidopsis, revealed the presence of four proteins, closely related to Brahma-complex of Drosophila [33]. The most studied proteins among them are SPLAYED (SYD) and BRAHMA (BRM), controlling a temporary regulation of the phases of plants development. SYD is responsible for the transition between vegetative and 
generative development and is necessary for normal development of carpel and seed-bud. Multiple pleiotropic defects were revealed in syd mutants, which prove the regulation of a wide spectrum of transcription events by specific members of SWI-SNF-family [38]. SYD also controls specification of the cells in apical meristem of the stalk [39].

BRAHMA is responsible for the size of plants and time of blossoming via repression of genes of photoperiodism. The results of molecular and morphological analysis allowed the assumption that syd- and brm-mutants demonstrate both similar and different defects. AtBRM controls the development of the stalk and process of blossoming [40]. Both mutants of these genes grow slowly, demonstrate brachysm and decreased apical domination in the stalk [38], as well as early blossoming [25]. Similar phenotypes were also described for mutants of other components of SWI-SNF complex.

Deacetylation of histones. Both in plants and in animals, $\mathrm{Rb}$-protein binds to histone deacetylases via $\mathrm{Rb}$-associated plant homologue of animal protein RbAp48 [41] (Fig.2, $b$ ).

Histone deacetylases are the enzymes, influencing transcription via selective deacetylation of $\varepsilon$-aminogroup of lysine, located in $\mathrm{N}$-terminal domains of histones. In plants, lysines 5, 8, 12, 16, 20 in $\mathrm{H} 4$ and 9, 14, 18, 23 in $\mathrm{H} 3$ are acetylated by HAT and deacetylated by HDAC [42]. The interaction between HAT and HDAC affects the dynamic equilibrium between acetylation and deacetylation of histones in the promoters and regulatory sites of genes, influencing chromatin structure and transcription. Histone acetylation promotes the reparation and recombination of DNA. Deacetylation of chromatin correlates with its condensed state and gene silencing. In humans, the disruption of HDAC functioning is observed in many forms of oncological diseases. HDAC binds to specific loci of chromosomes and joins DNA-binding proteins, regulating development directly or via additional factors. It was shown that in mammals the HDAC-Rb-E2F complexes are required for deacetylation of nucleosomes, located within the scope of gene promoter of cycline $\mathrm{E}(\mathrm{CycE})$ ) which impacts on its repression in the early $\mathrm{G}_{1}$-phase [10].
It is noteworthy that the expression of genes of deacetylases depends on the state of intracellular network of actin. For instance, it was proven on the culture of HeLa cells that depolymerization of F-actin results in the appearance of a multitude of soluble forms of deacetylases [43], thus regulating their activity.

18 assumed homologues of HDAC and 12 of HAT were found in Arabidopsis which is approximately equal to the number of these proteins in animals. In general, these HDAC are conservative in all eukaryotes. In Arabidopsis the most studied deacetylase is AtHD1 (HDA19) (RPD3 in yeasts), and similar members of family of deacetylases HDA6-7 and 9 were revealed. AtHD1 regulates the expression of various groups of genes during the development of flowers and leaves both positively and negatively [44]. HDA19 is highly expressed in leaves, stalks, flowers, and fresh pods and is involved in transcription repression $[44,45]$. Histone $\mathrm{H} 4$ is hyperacetylated in transgenic plants of Arabidopsis with antisense orientation of HAD19 gene; these plants demonstrate pathologies in the development, including early aging, suppression of apical domination, masculine and feminine sterility, and delay in blossoming [46]. HDA19 is one of the elements of repression of genes, responsible for the formation of roots in Arabidopsis stalk in embryogenesis [47].

Other members of this family of genes are presented by eight $R P D / H D I$-like genes, two homologues of yeast SIR2, possessing NAD+-dependent activity of HDAC [48], and four specific for plants genes of HD2 protein with unknown functions [44]. Different members of this group of genes are likely to be responsible for different functions. HD2 of corn is specific and not related to other known HDAC-enzymes [49]. It is localized in the nucleolus which presupposes its role in the regulation of genes of ribosomal RNA. The sequences of four products of genes in Arabidopsis (HDA4, HDA3, HDA11, and HDA13) demonstrate high homology to the sequence of protein HD2 in corn [50]. HDA3 is known by its role in the embryonic development. In transgenic plants with antisense $H D A 3$ the growth of pods is delayed, they have many aborted seeds which testify to the participation of HDA3 in the development 
of fetus. HDA6 was found to play a significant role in supporting methylation in CG nucleotides, but its contribution to the development is minimal, as the mutants deficient of the gene expression have normal phenotype.

Methylation of histones and DNA. The other mechanism of gene silencing in heterochromatin, related to the $\mathrm{Rb}-\mathrm{E} 2 \mathrm{~F} / \mathrm{DP}$ signaling pathway, is methylation of histones and DNA [51, 52] (Fig.2, c). Acetylation of specific residues of lysine at $\mathrm{N}$-terminal of histones $\mathrm{H} 3$ or $\mathrm{H} 4$ is mainly associated with the activation of transcription, while methylation of these residues is related either to transcriptional activity or to its repression depending on the methylated lysine and the number of methyl groups. It is believed that the markers of repressed structure of chromatin are methylation of $\mathrm{H} 3 \mathrm{~K} 9$, H3K27, and $\mathrm{H} 4 \mathrm{~K} 20$ in combination with hypoacetylation of histones and DNA methylation, as it influences the formation of heterochromatin, inactivation of X-chromosome and gene silencing in euchromatin. Methylation of H3K4, $\mathrm{H} 3 \mathrm{~K} 36$, and $\mathrm{H} 3 \mathrm{~K} 79$, and hyperacetylation of histone $\mathrm{H} 4$ are the markers of an open structure of chromatin (potentially transcriptional).

Moreover, monomethylation of H3K9, H3K27, and $\mathrm{H} 2 \mathrm{~K} 79$ is related to activation of transcription, and three-methylation of these three residues is associated with inhibition of gene expression [53, 54]. Intense methylation of lysine 4 (K4) and weak methylation of lysine 9 (K9) are considered [as the] modifications of histone H3, typical for transcriptionally active euchromatin. Euchromatin-specific methylation of H3K4 and H3K36 is highly conservative among eukaryotes, while marking heterochromatin by methylation of $\mathrm{H} 3 \mathrm{~K} 9, \mathrm{H} 3 \mathrm{~K} 27$, and $\mathrm{H} 4 \mathrm{~K} 20$ is more variable [42].

Two types of distribution of methylated H3K9, were revealed in plants depending on the size of genome. For plants with a small genome $-<500 \cdot 10^{6}$ B.P. (including Arabidopsis) - intense methylation of H3K9 is limited by the area of constitutive heterochromatin. Methylated H3K9 is distributed more evenly in plants with a large genome. To the contrast and regardless of genome size, methylation of $\mathrm{H} 3 \mathrm{~K} 4$ increases in euchromatin of all kinds. It is assumed that large genomes with numerous scattered repeated sequences should keep these sequences in inactive state. Therefore, such epigenetic changes as methylation of DNA and $\mathrm{H} 3 \mathrm{~K} 9$ are revealed in euchromatin as well [53].

The proteins, capable of methylating residues of lysine in histones $\mathrm{H} 3$ and $\mathrm{H} 4$, contain general SET-domain, consisting of 130 amino acid residues, called by three proteins of Drosophila, involved in epigenetic modifications - Su(var)3-9 (suppressor of variegation 3-9), Enhancer of zeste, Trithorax [55]. SET-domain proteins regulate chromatine activity and epigenetic inheritance (Fig.2, c). Some SET proteins are related to the members of Polycomb (PcG) or Trizorax (trxG) groups, repressing or activating the transcription of homeotic genes in the process of development of plants and animals.

Genome of Arabidopsis contains genes for 32 SET-proteins, 30 of which are expressed. They are divided into four conservative families $-E(Z)$, TRZ, ASH1 and Su(var)3-9 - and the small fifth family, which is plant specific [56]. Multitude of genes for SET-proteins in Arabidopsis genome proves the fact that methylation of histones serves as a regulatory factor in different aspects of gene expression, including the control over development genes. The family of $\mathrm{Su}$ (var)3-9 methyltransferases of histones is the most studied one. Two members of this family (KRYPTONITE (KYP)/SUVH4 and SUVH2) control dimethylation of $\mathrm{H} 3 \mathrm{~K} 9$ of heterochromatin and function in vivo as heterochromatin-specific H3K9-methyltransferases [57], SUVH2 being more active in the methylation of lysine 9 and 27 in H3 of heterochromatin. Mutant kyp is a repressor of gene silencing in locus SUPERMAN in Arabidopsis. Kyp-mutants demonstrate no morphological defects of wild type, which gives ground for assumption that KYP does not participate directly in controlling the plant development [58]. In this group Arabidopsis also has nine active genes SUVH (SUVH1-SUVH9) and five $S U V R$-genes [59], SUVR-proteins are specific SET-domain proteins of plants. Other SET-proteins methylate $\mathrm{K} 4, \mathrm{~K} 9, \mathrm{~K} 27$, and $\mathrm{K} 36$ in $\mathrm{H} 3$ or $\mathrm{K} 20$ in $\mathrm{H} 4$.

Human methyltransferases SUV39H1 and $\mathrm{KYP} / \mathrm{SUVH} 4$ methylate H3K9 in a specific way and create a code for attraction of HP1 (conservative protein of heterochromatin 1). HP1 and its homologues 
are key components of heterochromatin in yeasts, Neurospora, Drosophila, mammals, and plants. It is assumed that HP1 protein acts as an organizer of chromatin, participating in the assembling of multi-protein complexes, promoting gene silencing of euchromatin and expression of certain genes of heterochromatin. HP1 contains so called chromodomain and chromo shadow domain. Chromodomain HP1interacts with H3K9 specifically, which explains association of these proteins with heterochromatin [60].

Subsequent oligomerization of HP1 via chromo shadow domain expands and supports heterochromatin structures, thus providing gene silencing [25]. The only gene, coding for protein LHP1 (LIKE HP1), analogue of HP1, was revealed in Arabidopsis [57]. In Arabidopsis LHP1 is active not in heterochromatin, but in sites of euchromatin predominantly, where it represses the specific genes of development. The mutations in gene LHP1 because early blossoming, decrease in the number of epidermal cells in leaves and other features [61].

Therefore, LHP1 may be required for gene silencing, involved in the transition to blossoming and other processes of development.

However, not only methylation of H3K9 attracts HP1; other HP1-interacting proteins may be involved in this process too, for instance, retinoblastoma [62]. In humans SET-domain-methyltransferase Suv39H1 is bound to $\mathrm{Rb}$ and methylates lysine 9 of histone $\mathrm{H} 3$ in a specific way, repressing the activity of E2F [63]. Therefore, the repression of transcription of E2F-regulated genes of Suv39H1 is mediated by binding HP1 protein with methylated $\mathrm{H} 3$.

The presence of LHP1 protein in plants proves the existence of the LHP-HMT-Rb-E2F-complexes, repressing the work of $E 2 F$-genes [61, 64].

The repression of transcription is also achieved via direct methylation of DNA. DNA methylation is known to occur in the process of development in response to environmental factors [65]. Increased level of DNA methylation was found in plants from Chernobyl zone in the first years after the catastrophe [66], which testifies to the significance of epigenetic changes in DNA in adaptation to chronic radiation. In animals, DNA is methylated mainly as a result of methylation of cytosine in symmetric CG-nucleotides, while in plants cytosine is methylated not only in CG, but also in $\mathrm{CNG}(\mathrm{N}-$ any nucleotide) and $\mathrm{CHH}(\mathrm{H}=\mathrm{A}$, $\mathrm{C}$ or T) [65, 67]. There are three classes of DNA-methyltransferases in Arabidopsis genome.

It is believed that methyltransferase1 (MET1) (homologue of animal Dnmt1) is required to maintain methylated DNA structure. In plants, the methylation of CNG catalyzes the second class of methyltransferases - chromomethylase 3 (CMT3), specific for plants. CMT also performs asymmetric methylation of $\mathrm{CHH}$ in a locus-specific way $[42,67]$. The last class among presently known ones - domain rearranged methyltransferases (Dnm3) - is homologous of animal Dnmt3 [67, 68] and performs methylation de novo of cytosine residues in both symmetric and asymmetric motifs.

In mammals, DNA-methyltransferase is bound to the $\mathrm{Rb}-\mathrm{E} 2 \mathrm{~F}$ complex and represses the transcription of genes containing promoters with E2F binding sites. Contrary to plants, in animals the loss of function of any methyltransferase leads to death.

Various types of modifications of histones and DNA are assumed to interact with each other, and existing modifications of histones cause the subsequent ones [14]. The analysis of mutations regarding genes of methyltransferases of histones with SET-domain in Neurospora and Arabidopsis revealed that the methylated histones serve as a basis for DNA methylation [55]. For instance, protein LHP1 and its homologues are bound to H3K9me1,2 and attract DNA methyltransferases. The mutations kyp decrease the level of methylation of H3K9 in certain loci in vivo and reduce the DNA methylation in CNG sites. It is likely that H3K9 methylation controls CNG-methylation of DNA.

However, in plants DNA methylation does not always depend on histone methylation [26]. This is one of the reasons to state that DNA methylation precedes histone methylation [69]. It is assumed that DNA methylation in CG-sequences promotes methylation of H3K9 histones in chromocenters. Changes in the level of DNA methylation are accompanied by relaxation of chromocenters of heterochromatin. Contrary to methylation in CG-sites, methylation outside of CG does not influence histone methylation, but, in its turn, 
histone methylation regulates DNA methylation in CNG-sites. The mutants regarding genes H3K9me2-specific methyltransferase of histones KYP/SUVH4 and DNA-methyltransferase CMT3 do not contain methylated residues of cytosine in CNG-sites. It is believed that methylation of both $\mathrm{H} 3 \mathrm{~K} 9$ and $\mathrm{H} 3 \mathrm{~K} 2$ is required to attract CMT3. Besides, the activity of methyltransferase of histones SUVH2, participating in methylation of all heterochromatin-specific marks, depends on MET1, but not on CMT3 [42].

The discovery in mammals of locus $d d m 1$, coding for protein, homologous to ATFase sw12/snf2 of yeasts, which remodels chromatin, testifies to the fact that changes at the level of nucleosome can influence DNA methylation and gene expression. The most probable hypothesis states that remodeling activity of DDM1 enhances the accessibility of DNA-methyltransferases for semi-methylated DNA in newly-replicated chromatin. This assumption explains intense influence of ddm1 on DNA methylation in compact heterochromatin in comparison to euchromatin sites [25].

Therefore, at present it is evident that the processes of methylation of histones and DNA are related in complicated way.

Genetic studies on a number of genes, coding for the components of factors of restructuring chromatin HDAC, HMT, and DNMT, demonstrated that epigenetic mechanisms are conservative, and act at many stages of the plant development, including proliferation of embryo and meristem tissues and cell differentiation [29].

The covalent modifications are reverse. Regardless of the fact that HAT and HDAC perform reverse acetylation/deacetylation of histones, their methylation is stable. It is assumed that reverse acetylation/deacetylation of histones coordinates the reception of signals from the environment, thus regulating plant development. The external signals are realized through the action of transcription activators, repressors and/or molecules, involved in signal transmission. Such molecules attract deacetylases of histones to the promoters [of genes, sensitive to environmental factors and influencing the development, which, in its turn, rebuilds chromatin and either activates or represses the transcription of certain genes. Since this process is reverse, an increased transcription may come back to "normal" in the absence of signal [44].

The association of chromatin-modulating factors with the Rb-E2F-signalling pathway leads to the assumption that there is epigenetic control over cell division and differentiation. The study on details of this interrelation will allow revealing the mechanism of influence of environment on the plant morphogenesis. The reverse nature of chromatin silencing is of significant interest for oncobiology and transgenic technologies. Besides, the spatial and temporal differences in vegetative and regenerative phases of the plant development permit to study the epigenetic inheritance of specific chromatin structures, acquired during the vegetative development. The inheritance of these changes and their role during the plant evolution is a subject of further studies.

\section{Г. В. Шевченко}

Клеточный цикл и эпигенетические изменения ДНК у растений Резюме

Для минимизации влияния внешней среды растения используют несколько стратегий. Одна из них - наследуемые модификаиии генной экспрессии, осуществляемые без изменения последовательности нуклеотидов ДНК (эпигенетика). Сигнальный путь $R b-E 2 F / D P$ (ретинобластома (Rb)-транскрипционные фактоpы E2F/DP) связывает клеточный ичкл и факторы модификаиии ДНК и хроматина, а также координирует клеточную пролиферацию и дифференциацию в зависимости от внешних воздействий. В обзоре систематизированы данные об активности сигнального пути $R b-E 2 F / D P$ и его связи с эпигенетическими изменениями ДНК у растений.

Ключевые слова: ДНК, транскрипционный фактор Е2F, хроматин-ремодулирующие комплексы, эпигенетика.

\section{Г. В. Шевченко}

Клітинний цикл і епігенетичні зміни ДНК у рослин

Резюме

Щоб мінімізувати вплив довкілля рослини використовують декілька стратегій. Одна з них - це наслідування модифікацій генної експресії, які відбуваються без зміни послідовності нук- 
леотидів ДНК (епігенетика). Сигнальний шлях $R b-E 2 F / D P$ (ретинобластома (Rb)-транскрипиійні фактори E2F/DP) поєднує клітинний цикл з факторами модифікації ДНК і хроматину та координує проліферацію $і$ диференціацію клітин залежно від зовнішнього впливу. В огляді систематизовано дані шеодо активності сигнального шляху $R b-E 2 F / D P$ і його зв 'язку $з$ епігенетичними змінами ДНК у рослин.

Ключові слова: ДНК, транскрипційний фактор E2F, комплекси, шчо ремодулюють хроматин, епігенетика.

\section{REFERENCES}

1. Inze D., de Veylder L. Cell cycle regulation in plant development // Annu. Rev. Genet.-2006.-40, N 1.-P. 77-105.

2. Gutierrez $C$. The retinoblastoma pathway in plant cell cycle and development // Curr. Opin. Plant Biol.-1998.-1, N 6.P. 492-497.

3. Dewitte W., Murray J. The plant cell cycle// Annu. Rev. Plant Biol.-2003.-54, N 1.-P. 235-264.

4. Harbour J., Dean, $D$. The Rb/E2F pathway: expanding roles and emerging paradigms // Genes Develop.-2000a.-14, N 19.-P. 2393.

5. De Veylder L., Beeckman T., Beemster G., de Almeida Engler J., Ormenese S., Maes S., Naudts M., van der Schueren E., Jacqmard A. Control of proliferation, endoreduplication and differentiation by the Arabidopsis E2Fa-Dpa transcription factor // EMBO J.-2002.-21, N 6.-P. 1360-1368.

6. Blais A., Dynlacht B. E2F-associated chromatin modifiers and cell cycle control // Curr. Opin. Cell Biol.-2007.-19, N 6.-P. 658-662.

7. Sekine M., Ito M., Uemukai K., Maeda Y., Nakagami H., Shinmyo A. Isolation and characterization of the E2F-like gene in plants // FEBS Lett.-1999.-460, N 1.-P. 117-122.

8. Albani D., Mariconti L., Ricagno S., Pitto L., Moroni C., Helin $K$., Cella $R$. DcE2F, a functional plant E2F-like transcriptional activator from $D$. carota // J. Biol. Chem.-2000.275, N 25.-P. 19258-19267.

9. Kosugi S., Ohashi Yu. Constitutive E2F expression in tobacco plant exhibits altered cell cycle control and morphological changes in a cell type specific manner // Plant Physiol.2003.-132, N 4.-P. 2012-2022.

10. Sabelli P. A., Dante R. A., Leiva-Neto J. T., Jung R., GordonKamm W. J., Larkins B. A. RBR3, a member of the retinoblastoma-related family from maize is regulated by the RBR1/E2F pathway // Proc. Nat. Acad. Sci. USA.-2005.102, N 37.-P. 13005-13012.

11. Vandepoele K., Raes J., De Veylder L., Rouze P., Rombauts $S$., Inze $D$. Genome-wide analysis of core cell cycle genes in Arabidopsis // Plant Cell.-2002.-14, N 4.-P. 903-916.

12. Oakenfull E., Riou-Khamlichi C., Murray J. Plant D-type cyclins and the control of G1 progression // Phil. Trans. Roy. Soc. Lond.-2002.-357, N 1422.-P. 749-760.

13. Mariconti L., Pellegrini B., Cantoni R., Stevens R., Bergounioux $C$., Cella R., Albani D. The E2F family of transcription factors from A. thaliana: novel and conserved components of plant retinoblastoma/E2F pathway in plants // J. Biol. Chem.2002.-277, N 12.-P. 9911-9919.

14. Shen $W$. The plant E2F-Rb pathway and epigenetic control// Trends Plant Sci.-2002.-7, N 11.-P. 505-511.
15. Kovesdi I., Reichel R., Nevins J. R. Identification of a cellular transcription factor involved in E1A transactivation // Cell.1986.-45, N 2.-P. 219-228.

16. Lavia P., Jansen-Durr P. E2F target genes and cell-cycle checkpoint control // BioEssays.-1999.-21, N 3.-P. 221230.

17. De Jager S., Menges M., Bauer U., Murray J. Arabidopsis E2F-1 binds a sequence present in the promoter of S-phaseregulated gene AtCDC6 and is a member of a multigene family with differential activities // Plant Mol. Biol.-2001.47, N 4.-P. 555-568.

18. Kosugi $S$., Ohashi Yu. E2F sites that interact with E2F protein cloned from rice are required for meristematic tissue-specific expression of rice and tobacco proliferating cell nuclear antigen promoters // Plant J.-2002.-29, N 1.-P. 45-59.

19. Del Pozo J., Boniotti M., Gutierrez C. Arabidopsis E2Fc functions in cell division and is degraded by the ubiquitin-SCF (AtSKP2) pathway in response to light // Plant Cell.-2002.14, N 12.-P. 3057-3071.

20. Ramirez-Parra E., Lopez-Matas M.A., Frundt C., Gutierrez $C$. Role of an atypical E2F transcription factor in the control of Arabidopsis cell growth and differentiation // Plant Cell.2004.-16, N 9.-P. 2350-2363.

21. Sozzani R., Maggio C., Varotto S., Canova S., Bergounioux C., Albani D., Cella R. Interplay between Arabidopsis activating factors $\mathrm{E} 2 \mathrm{Fb}$ and $\mathrm{E} 2 \mathrm{Fa}$ in cell cycle progression and development // Plant Physiol.-2006.-140, N 4.-P. 13551366.

22. Shan B., Lee W. Deregulated expression of E2F-1 induces Sphase entry and leads to apoptosis // Mol. Cell Biol.-1994.14, N 1.-P. 8166-8173.

23. Chaboute M., Clement B., Sekine M., Philipps G., ChaubetGigot N. Cell cycle regulation of the tobacco ribonucleotide reductase small subunit gene is mediated by E2F-like elements // Plant Cell.-2000.-12, N 10.-P. 1987-2000.

24. Stevens R., Mariconti L., Rossignol P., Perennes C., Cella R., Bergounioux $C$. Two E2F sites in the Arabidopsis MCM3 promoter have different roles in cell cycle activation and meristematic expression // J. Biol. Chem.-2002.-277, N 30.P. 32978-32984.

25. Reyes J., Hennig L., Gruissem W. Chromatin-remodeling and memory factors. New regulators of plant development // Plant Physiol.-2002.-130, N 3.-P. 1090-1101.

26. Martin C., Zhang Yi. Mechanisms of epigenetic inheritance// Curr. Opin. Cell Biol.-2007.-19, N 3.-P. 266-272.

27. Vignali M., Hassan A., Neely K., Workman J. ATP-dependent chromatin-remodelling complexes // Mol. Cell. Biol.-2000.20, N 6.-P. 1899-1910.

28. Saha A., Wittmeyer J., Cairns B. Chromatin remodeling: the industrial revolution of DNA around histones // Nat. Rev. Mol. Cell Biol.-2006.-7, N 6.-P. 437-447.

29. Bezhani S., Winter C., Hershman S., Wagner J., Kennedy J., Kwon Ch., Pfluger J., Su Ya., Wagner D. Unique, shared, and redundant roles for the Arabidopsis SWI/SNF chromatin remodeling ATPases BRAHMA and SPLAYED // Plant Cell.2007.-19, N 2.-P. 403-416.

30. Mohrmann L., Verrijzer C. Composition and functional specificity of SWI2/SNF2 class chromatin remodeling complexes // Biochim. Biophys. Acta.-2005.-1681, N 2-3.-P. 5973.

31. Flaus A., Martin D., Barton G., Owen-Hughes T. Identification of multiple distinct Snf2 subfamilies with conserved 
structural motifs // Nucl. Acids Res.-2006.-34, N 10.P. 2887-2905.

32. Sarnowski T., Swiezewski Sz., Pawlikowska K., Kaczanowski Sz., Jerzmanowski A. AtSWI3B, an Arabidopsis homolog of SWI3, a core subunit of yeast Swi/Snf chromatin remodeling complex, interacts with FCA, a regulator of flowering time // Nucl. Acids Res.-2002.-30, N 15.-P. 3412-3421.

33. Verbsky M., Richards E. Chromatin remodeling in plants // Curr. Opin. Plant Biol.-2001.-4, N 6.-P. 494-500.

34. Harbour J., Dean D. Chromatin remodeling and Rb activity // Curr. Opin. Cell Biol.-2000.-12, N 6.-P. 685-689.

35. Sarnowski T., Rios G., Swiezewski Sz., Kaczanowski Sz., Li Y., Kwiatkowska A., Pawlikowska K., Kozbial M., Kozbial P., Concz C., Jerzmanowski A. SWI3B subunits of putative SWI/ SNF chromatin remodeling complex play distinct roles during Arabidopsis development // Plant Cell.-2005.-17, N 9.P. 2454-2472.

36. Peterson C., Zhao J., Chait B. Subunits of the yeast SWI/SNF complex are members of the actin-related protein (ARP) family // J. Biol. Chem.-1998.-273, N 37.-P. 23641-23644.

37. Chen $M$., Shen $X$. Nuclear actin and actin-related proteins in chromatin dynamics // Curr. Opin. Cell Biol.-2007.-19, N 3.-P. 326-330.

38. Kwon C., Hibara K., Pfluger J., Bezhani S., Metha H., Aida M., Tasaka M., Wagner D. A role for chromatin remodeling in regulation of CUC gene expression in the Arabidopsis cotyledon boundary // Development.-2006.-133, N 16.- P. 32233230.

39. Su Y., Kwon G., Bezhani S., Huvermann B., Chen C., Peragine A., Kennedy J., Wagner D. The N-terminal ATPase AThook containing region of the Arabidopsis-remodelling protein SPLAYED is sufficient for biological activity // Plant J.-2006.-46, N 4.-P. 685-699.

40. Farrona S., Hurtado L., Bowman J., Reyes J. The Arabidopsis thaliana SNF2 homolog AtBRM controls shoot development and flowering // Development.-2004.-131, N 20.-P. 49654975.

41. Lusser A., Kolle D., Loidl P. Histone acetylation: lessons from the plant kingdom // Trends Plant Sci.-2001.-6, N 2.P. 59-65.

42. Fuchs J., Demidov D., Houben A., Schubert I. Chromosomal histone modification patterns - from conservation to diversity // Trends Plant Sci.-2006.-11, N 4.-P. 199-208.

43. Andrin Ch., Hendzel M. F-actin dependent insolubility of chromatin-modifying components // J. Biol. Chem.-2004.279, N 24.-P. 25017-25023.

44. Tian L., Fong M., Wang J., Wei N., Jiang H., Doerge R., Chen $Z$. Reversible histone acetylation and deacetylation mediate genome-wide, promoter-dependent and locus-specific changes in gene expression during plant development // Genetics.-2005.-169, N 1.-P. 337-345.

45. Wu K., Malik K., Tian L., Brown D., Miki B. Functional analysis of a RPD3 histone deacetylase homologue in A. thaliana // Plant Mol. Biol.-2000.-44, N 2.-P. 167-176.

46. Tian L., Chen Z. Blocking histone deacetylation in Arabidopsis induces pleiotropic effects on plant gene regulation and development // Proc. Nat. Acad. Sci. USA.-2001.-98, N 1.P. 200-205.

47. Rossi V., Locatelli S., Varotto S., Donn G., Pirona R., Henderson D., Hartings H., Motto M. Maize histone deacetylase hda101 is involved in plant development gene transcription and sequense-specific modulation of histone modification of genes and repeats // Plant Cell.-2007.-19, N 4.-P. 11451162 .
48. Khochbin S., Verdel A., Lemercier C., Seigneurin-Berny D. Functional significance of histone deacetylase diversity // Curr. Opin. Genet. Devel.-2001.-11, N 2.- P. 162-166.

49. Lusser A., Brosch G., Loidl A., Haas H., Loidl P. Identification of maize histone deacetylase HD2 as an acidic nucleolar phosphoprotein // Science.-1997.- 277, N 5322.-P. 88-91.

50. Wu K., Tian L., Malik K., Brown D., Miki B. Functional analysis of HD2 histone deacetylase homologues in Arabidopsis thaliana // Plant J.-2000.-22, N 1.- P. 19-27.

51. Harbour J., Dean D. Chromatin remodeling and Rb activity // Curr. Opin. Cell Biol.-2000.-12, N 6.-P. 685-689.

52. Fisher U., Kuhlmann M., Pecinka A., Schmidt R., Mette M. Local DNA features affects RNA-directed transcriptional gene silencing and DNA methylation // Plant J.-2008.-53, N 1.P. 1-10.

53. Nakayama J., Rice J., Strahl B., Allis C., Grewal S. Role of histone $\mathrm{H} 3$ lysine 9 methylation in epigenetic control of heterochromatin assembly // Science.-2001.-292, N 5514.P. 110-113.

54. Li X., Wang X., He K., Ma Y., Su N., He H., Stolc V., Tongprasit $W$., Jin $W$., Jiang J., Terzaghi $W$., Li S., Deng $X$. Highresolution mapping of epigenetic modifications of the rice genome uncovers interplay between DNA methylation, histone methylation and gene expression // Plant Cell.-2008.-20, N 2.-P. 259-276.

55. Jackson J., Johnson L., Jasencakova Z., Zhang X., PerezBurgos L., Singh P., Cheng X., Schubert I., Jenuwein T., Jacobsen $S$. Dimethylation of histone H3 lysine 9 is a critical mark for DNA methylation and gene silencing in A. thaliana // Chromosoma.-2004.-112, N 6.-P. 308-315.

56. Springer N., Napoli C., Selinger D. Comparative analysis of SET-domain proteins inmaize and Arabidopsis reveals multiple duplications preceding the divergence of monocots and dicots // Plant Physiol.-2003.-132, N 2.-P. 907-925.

57. Jackson J., Lindroth A., Cao X., Jacobsen S. Control of CpNpG DNA methylation by the KRYPTONITE histone H3 methyltransferase // Nature.-2002.-416, N 6880.-P. 556560 .

58. Naumann K., Fischer A., Hofmann I., Krauss V., Phalke S., Irmler K., Hause G., Aurich A., Dorn R., Jenuwein T., Reuter $G$. Pivotal role of AtSUVH2 in heterochromatic histone methylation and gene silencing in Arabidopsis // EMBO J.2005.-24, N 7.-P. 1418-1429.

59. Chan S., Henderson I., Jacobsen S.Gardening the genome: DNA methylation in Arabidopsis thaliana // Nat. Rev. Genet.-2005.-6, N 12.-P. 351-360.

60. Bannister A., Zegerman P., Partridge J., Miska E., Thomas J., Allshire R., Kouzarides T. Selective recognition of methylated lysine 9 on histone H3 by the HP1 chromodomain // Nature.-2000.-410, N 6824.-P. 120-124.

61. Gaudin V., Libault M., Pouteau S., Juul T., Zhao G., Lefebvre G., Grand-Jean O. Mutations in like heterochromatin protein 1 affects flowering time and plant architecture in Arabidopsis // Development.-2001.-128, N 23.-P. 4847-4858.

62. Zemah A., Li Yan., Ben-Meir H., Oliva M., Mosquna A., Kiss V., Avivi Y., Ohad N., Grafi G. Diferent domains control the localization and mobility of LIKE HETEROCHROMATIN PROTEIN 1 in Arabidopsis nuclei // Plant Cell.-2006.-18, N 1.- P. 133-145.

63. Nielsen S., Schneider R., Bauer U., Bannister A. J., Morrison A., O'Carroll D., Firestein R., Cleary M., Jenuwein T., Herrera $R$., Kouzarides $T$. Rb targets histone $\mathrm{H} 3$ methylation and HP1 to promoters // Nature.-2000.-412, N 6846.-P. 561565. 
64. Williams L., Grafi G. The retinoblastoma protein-a bridge to heterochromatin // Trends Plant Sci.-2000.-5, N 7.-P. 239240.

65. Penterman J., Uzawa R., Fischer R. Genetic interactions between DNA demethylation and methylation in Arabidopsis // Plant Physiol.-2007.-145, N 4.-P. 1549-1557.

66. Kovalchuk I., Abramov V., Pogribny I., Kovalchuk O. Molecular aspects of plant adaptation to life in the Chernobyl zone // Plant Physiol.-2004.-135, N 1.-P. 357-363.

67. Singh A., Zubko E., Meyer P. Cooperative activity of DNA methyltransferases for maintenance of symmetrical and non- symmetrical cytosine methylation in Arabidopsis thaliana // Plant J.-2008.-56, N 4.-P. 814-823.

68. Boyko A., Kovalchuk I. Epigenetic control of plant stress response // Environ. Mol. Mutagen.-2008.-49, N 1.-P. 61-72.

69. Soppe W., Jasencakova Z., Houben A., Kakutani T., Meister A., Huang M., Jacobsen S., Schubert J., Fransz P. F. DNA methylation controls histone $\mathrm{H} 3$ lysine 9 methylation and heterochromatin assembly in Arabidopsis // EMBO J.-2002.21, N 23.- P. 6549-6559. 